\title{
Winching Distance in Function of the Optimization of Skid Network
}

\author{
Darko Ljubojević ${ }^{1}$, Milorad Danilović $^{2}$, Dane Marčeta ${ }^{3 *}$, Vladimir Petković ${ }^{3}$
}

(1) Public Forest Company "Šume Republike Srpske" a.d. Sokolac, FM "Prijedor", Vožda Karađorđa 4/2, BA-79101 Prijedor, Bosnia and Herzegovina; (2) University of Belgrade, Faculty of Forestry, Kneza Viseslava 1, RS-11030 Belgrade, Serbia; (3) University of Banja Luka, Faculty of Forestry, Stepe Stepanovica 75a, BA-78000 Banja Luka, Bosnia and Herzegovina

* Correspondence: e-mail: dane.marceta@sf.unibl.org
Citation: LJUBOJEVIĆ D, DANILOVIĆ M, MARČETA D, PETKOVIĆ V 2018 Winching Distance in Function of the Optimization of Skid Network. South-east Eur for 9 (2): 97-106. DOI: https://doi.org/10.15177/ seefor.18-14

Received: 22 Aug 2018; Revised: 9 Nov 2018; Accepted: 12 Nov 2018; Published online: 10 Dec 2018

\begin{abstract}
Background and Purpose: Optimisation of skid road network is very important in forest utilisation because transport is considered to be the most expensive part of timber production. Designing forest traffic infrastructure means positioning its location in the forest area using traditional or modern methods. Many factors influence the skidding costs, and winching distance is one of them. The use of modern techniques gives an opportunity to forest practitioners that simulate different network variants and choose the most appropriate ones.

Materials and Methods: The research object is Compartment 27, which belongs to Forest Administration Unit "Prijedor", with the area of 46.72 ha. Investigation is divided into the phase of field work and the phase of designing secondary forest road network variants in the office. Field work includes the traditional and Global Positioning System (GPS) marking of trees for cutting and the creating of Geographic Information System (GIS) database. In relation to spatial distribution of trees for cutting, skid roads and skid trail networks are laid by using the GPS. The new scondary road network is laid in the field and compared with three simulated variants of secondary road network that are laid by ArcGIS 10.3. Secondary road network is planned by using Network Analyst tools and Shortest path method that is based on Dijkstra's algorithm. These variants are simulated based on different average winching distances of 10,20 and $30 \mathrm{~m}$.

Results: The area of the compartment is divided into two transportation zones. Total length of the secondary road network designed in the traditional way is $4816 \mathrm{~m}$, thus achieving the secondary openness of $103 \mathrm{~m} \cdot \mathrm{ha}^{-1}$. In simulated Variant I, with winch pulling distances of $20 \mathrm{~m}$, the total length of secondary roads is $5590 \mathrm{~m}$ with costs of $14352.62 €$, in Variant II with winching distance of up to $40 \mathrm{~m}$ length of secondary roads it is $3228 \mathrm{~m}$ with costs of $7426.78 €$, and in Variant III with winch rope length of up to $60 \mathrm{~m}$, the length of roads is $2219 \mathrm{~m}$, with costs of $4400.89 €$. The achieved mean skidding distances are relatively similar in all variants. When taking into account the average length of the winch rope, considering all three new-design variants, it can be said that there is almost no difference in productivity and skidding costs.

Conclusions: Mean winching distance has influence on skidding costs, but only in variants where mean skidding distance is decreasing. Smaller winching distance is justified only from the aspect of work humanization. Small differences in skidding costs between variants have no practical significance except for large quantities of wood assortments.
\end{abstract}

Keywords: skidding, simulation, rope length, Dijkstra algorithm

\section{INTRODUCTION}

In the mathematical sense, optimization means defining the minimal or maximal value of the real function. In sustainable forest management, from the point of timber usage, optimization means utilization of forests with minimal transport costs [1-3], while considering the rest of the forest users. Transport of timber is very important and the most expensive part of the timber production. According to Sokolović and Bajrić [4], transport costs amount to around $80 \%$ of total costs of the timber production and consist of the skidding costs and the costs of construction and maintenance of forest roads. The skidding costs are 20 to 30 times larger than the costs of long-disatnce transport [5]. The skidding costs consist of the costs of construction and maintenance of 
secondary forest roads and the unit costs of skidding. Secondary forest roads consists of skid roads and skid trails. Skid roads are constructed by excavation of soil with dozers or excavators. For the protection of skid road surface from erosion water bars are used, which are built diagonally over the skid road surface. Roadbed width of skid roads is $3.5 \mathrm{~m}$. Longitudinal grade of skid road should be $16 \%$ in order to protect the road from erosion of its surface, while skid road gradient should not exceed $30 \%$, especially when skidding uphill $[6,7]$. Skid trails are not specially constructed, but only after they are designed all trees from the route of the skid trail are cut $[5,8,9]$. They make a forest temporarily accessible and they are used for the extraction of timber from the harvesting area to the landing on the forest road. Also, they do not exempt from the productive forest area. The most common way of timber extraction in Europe, and particularly in Bosnia and Herzegovina $(\mathrm{BIH})$, is ground skidding with wheel skidders $[10,11]$.

The optimization of a secondary forest road network is very hard to present as mathematical or forest management problem. Dependence of the density of skid roads or other types of secondary forest roads on forest management can be observed as the targeted optimum. The density of secondary roads ranges from 100 to 200 $\mathrm{m} \cdot \mathrm{ha}^{-1}$ in $\mathrm{BIH}$ [5], depending on the forest management system which is applied for a certain category of forests. According to Rebula [12], secondary forest openness or needed density of skid roads and skid trails in young stands is around 250-300 $\mathrm{m} \cdot \mathrm{ha}^{-1}$, but in older stands, where trees are much more distant from one another, density is only $100-180 \mathrm{~m} \cdot \mathrm{ha}^{-1}$. In Slovenia the maximum allowable density of secondary forest roads depends of terrain configuration and amounts to $180 \mathrm{~m} \cdot \mathrm{ha}^{-1}$ for karst terrain, $150 \mathrm{~m} \cdot \mathrm{ha}^{-1}$ for hilly terrain, and $130 \mathrm{~m} \mathrm{~m} \cdot \mathrm{ha}^{-1}$ for mountainous terrain [13]. Pičman [14] stated that for hillymountainous areas $200 \mathrm{~m} \cdot \mathrm{ha}^{-1}$ represent good openness. In selective stands of Gorski Kotar the density of skid network is $150 \mathrm{~m} \cdot \mathrm{ha}^{-1}$ [15].

That task depends on the optimal density and spatial layout of forest roads, and the intensity of harvesting. Optimal density and spatial layout of forest roads influence relative forest accessibility, whose result is the defining of inaccessible forest areas. Relative forest accessibility depends on geometrical skidding distance. Also, the spatial layout of forest roads and terrain conditions defines the position of landings for timber. The intensity of harvesting depends on the number of marked trees and their quality. The extraction of timber is usually planned based on the assumption that timber is evenly distributed over the forest area, but as modern technologies are more widespread, tree marking by Global Positioning System (GPS) enables the planning of timber extraction based on the accurate position of marked trees [16].

Optimization of a secondary forest road network includes the designing of new skid roads and skid trails in parts of the compartment which are not accessible enough from the point of the extraction of marked trees. The design of secondary road network can be approached based on a traditional terrain job and vector or raster method [17]. The second and third approach of designing secondary roads are advanced methods based on using Geographic Information System (GIS) analysis.

Designing forest traffic infrastructure includes positioning of its location in the forest area by traditional or modern methods [18]. Traditional approach of designing a network of forest roads includes two different types of road network based on terrain conditions. It is recommended to use perpendicular secondary network on flat terrain and for the main parameter to be spacing. In steep terrain, the strategy of designing primary and secondary forest roads is based on defining the location of points which forest road or its segment has to connect. At this stage, forest road designing does not consider variability of forest stand conditions and harvesting technologies [19]. The modern approach of designing primary and secondary forest road networks consists of the vector, raster or graphic way of determination of forest road location $[17,20]$.

Vector approach is based on a computer algorithm which generates road networks from different factors that influence road designing. This method includes a sensitive analysis of affecting factors such as: total length of roads, the percentage of landings, slope, and horizontal and vertical alignment. This method improves the manual method of forest road designing, and it is suitable for strategic planning of forest road location [16].

Stückelberger et al. [21] developed an improved model of optimization of primary and secondary forest road network location based on connectivity of terminal points with shortest paths which were based on minimal transportation costs. Determination of shortest paths is carried out by using Dijkstra algorithm. These terminal points and links between them make a wire diagram. This model can determine suitable and the most cost-effective locations for forest roads in steep terrain.

Optimization of forest road location is carried out by heuristic algorithm, which should determine the most cost-effective location of forest roads for timber harvesting and the costs of production, skidding, construction and maintenance of forest roads. This method developed a tree-shape network of forest traffic infrastructure which evenly covers the forest area. It defines the variable costs as the unit skidding costs, while the fixed costs represent the costs of forest road construction and maintenance. Apart from information on the volume of timber in harvesting units, skidding and road network, and the landings by forest road or the saw mills, planning of forest road networks depends on terrain conditions such as slope and hydrology [23].

Najafi and Richards [24] have planned primary and secondary forest road network on the basis of minimal transportation costs, which provides cutting and transport activities by Mixed Integer Programming (MIP) method. Transportation costs were defined by the costs of construction and maintenance which were calculated based on segment length, terrain conditions, road standard, traffic volume and unit skidding costs. This research was based on the determination of cutting sites as points which will be connected with the least cost paths. Planning of primary forest road network was 
carried out by NETWORK 2000 software based on routes with minimal timber harvesting and extraction costs, for timber transport from harvest units to the sawmills or the market on the basis of the given link and sale data. These routes will be used for timber harvesting. Link data consist of information on primary forest road network, and fixed and variable costs. Sale data include information on timber harvesting units, timber destinations, volume and production year [25]. Suitability of forest area for construction of forest roads was determined on the basis of three influential factors: slope, soil and hydrology. Maps of these factors were divided into three categories which have high, moderate and low influence on construction costs of forest roads. The influence of these factors on the construction costs of forest roads was obtained on the basis of the experience of forest experts. The weight of slope is 0.63 , for soil it is 0.29 and for hydrology 0.08 . The designing of forest roads was conducted by PEGGER extension of ArcView, and it produced 9 alternatives [26].

Heinimann [19] has applied an optimal road strategy with a comprehensive spatial and statistical analysis of terrain and stand conditions of forest area and harvesting technology. Optimal road strategy depends on the definition of points which the forest road should connect. These points are cutting sites (compartments) from which timber should be transported with a skidder or cable yarder to landings on the forest road. They define timber volume, i.e. stand conditions of a forest area. Then, its strategy depends on the analysis of terrain conditions based on earlier field research, or the conditions derived from the Digital Terrain Model (DTM) or airborne Light Detection And Ranging (LiDAR) system.

Parsakhoo and Lotafalian [17] optimized skid road or trail network on the basis of the position of future landings and forest roads within the forest area by using weighted-graph optimization algorithm. This algorithm is based on minimization of skidding costs and construction costs of the forest road. The skidding costs showed optimal position of landings and optimal spatial layout of future forest roads. The construction costs of forest roads depend on their length and longitudinal grade, as well as terrain slope. The future landings are shown as points of cell size of DTM, and they are placed on the terrain with a slope of up to $10 \%$. The future forest roads are presented as the links between points with maximum length of $75 \mathrm{~m}$. The link connects the point with eight adjacent points, i.e. future landings.

The networks of the secondary forest road differ according to the winching distance which is achievable in certain terrain characteristics from the point of timber production costs. Winching is the phase of work in the roundwood extraction, or more precisely, in the skidding of roundwood. The most common way of roundwood extraction in $\mathrm{BIH}$ is skidding with wheel skidders [11]. In Croatia, wood bunching and extraction is performed by skidders equiped with one-drum or double-drum winches [27]. Bembenek et al. [28] showed that, during extration with tractors, the mean overal operational productivity was $30.05 \mathrm{~m}^{3} \cdot \mathrm{h}^{-1}$, with an average od $1.8 \mathrm{~m}^{3}$ of wood obtained from trees. Sabo and Poršinsky [29] established $11.6 \mathrm{~m}^{3} \cdot \mathrm{h}^{-1}$ achived by Timberjack $240 \mathrm{C}$ in a mountainous fir stand where the volume per mean marked tree was 3.9 $\mathrm{m}^{3}$, while by using a LKT 81T cable skidder in mountain conditions in an 82 year old fir stand productivity can reach $7.15 \mathrm{~m}^{3} \cdot \mathrm{h}^{-1}[30]$.

The cost of winching and the total cost of roundwood production is lower with the reduction of winching distance, while winching productivity is higher. The reduction of winching distance requires an increase of the length and density of secondary forest road network.

The aim of this paper is to define the most appropriate network of secondary forest roads. The results of this investigation should show that it is possible to completely replace the methods used so far with those based on heuristic algorithms integrated into ArcGIS platform, as well as that the analysis of secondary forest road network, especially from the point of different winch rope length (winching distance), could lead to reduced costs. These tasks are the result of the assumption that with changes in winching distances in the unique distribution of trees marked for cutting, skidding costs will differ. Within this assumption, changing winch rope length will lead to changes in skid network density. Smaller winch rope length consequently causes larger density of secondary roads in the compartment and vice versa.

\section{MATERIALS AND METHODS}

\section{Study Area}

The research object is Compartment 27, which belongs to Forest Administration Unit "Prijedor". It is located between the latitude of $16^{\circ} 52^{\prime} 4.612^{\prime \prime}$ and $16^{\circ} 52^{\prime} 42.153^{\prime \prime}$ and the longitude of $45^{\circ} 3^{\prime} 42.255^{\prime \prime}$ and $45^{\circ} 4^{\prime} 16.017^{\prime \prime}$ (Figure $1)$. The area belongs to moderate continental climate. The area of Compartment 27 is 46.72 ha and it is covered by forests of beech and fir. Management system is group selection. Total volume per ha amounts to $365.94 \mathrm{~m}^{3} \cdot \mathrm{h}^{-1}$, while volume increment is $8.34 \mathrm{~m}^{3} \cdot \mathrm{h}^{-1}$. The cutting of marked trees is carried out by the assortment harvesting method.

\section{Measurements}

Investigation is divided into two phases, field work and the designing of secondary road network variants in the office. Field work includes traditional and GPS marking of trees for cutting (Figure 2) and creating a GIS database that contains tree species, Diameter at Breast Height (DBH) of trees, technical class of marked trees, volume of marked trees, volume of roundwood and the group to which a marked tree belongs. Volume of roundwood of marked trees is obtained from assortment tables based on total wood volume, tree species, technical class and DBH class [31]. Technical classes are determined by guidelines defined in Drinic et al. [31].

In relation to the spatial distribution of trees for cutting, skid road and skid trail network is laid using the GPS device. Routes are imported in the ArcGIS database, where they are assigned with numbers from 1 to $n$ and their length. The aim of this investigation is related to the cost of secondary road network construction and the skidding cost. For the determination of mean winching and skidding distance the volume of roundwood is used. 

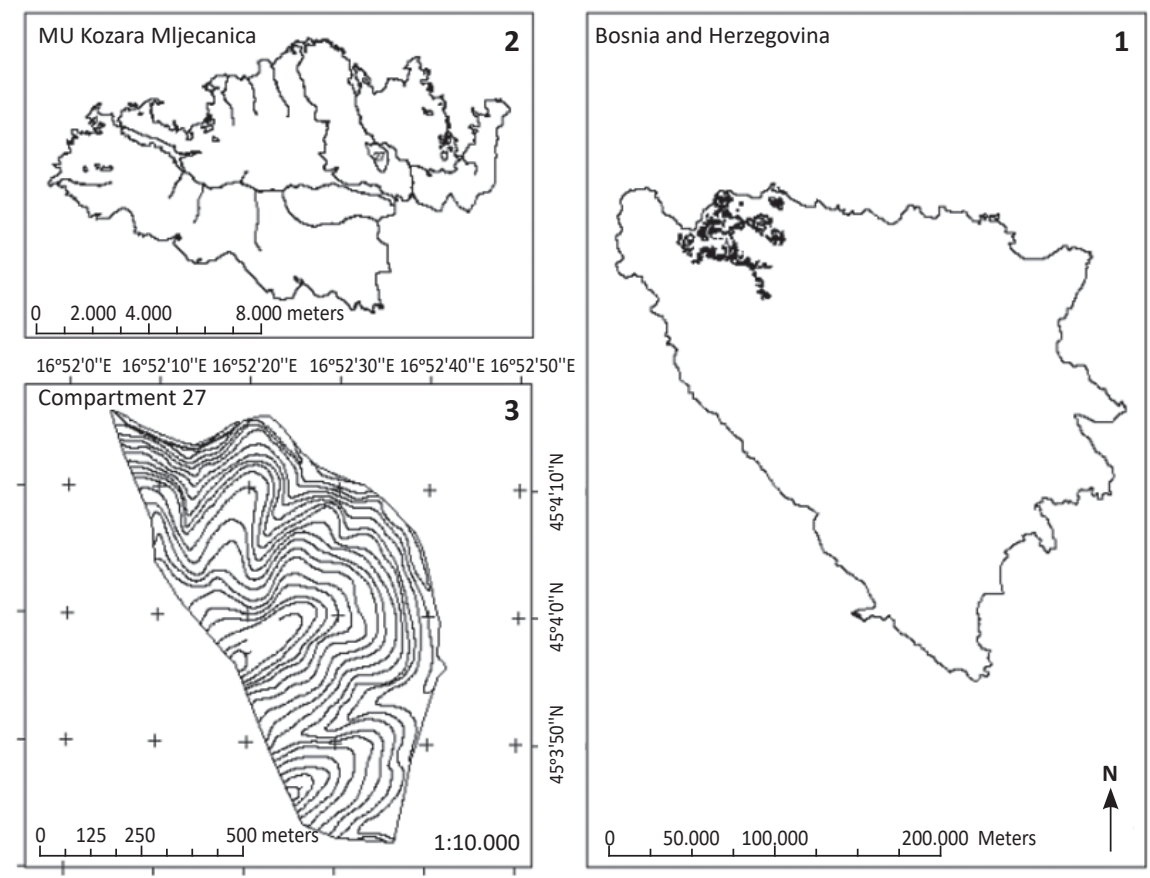

FIGURE 1. Area of research.

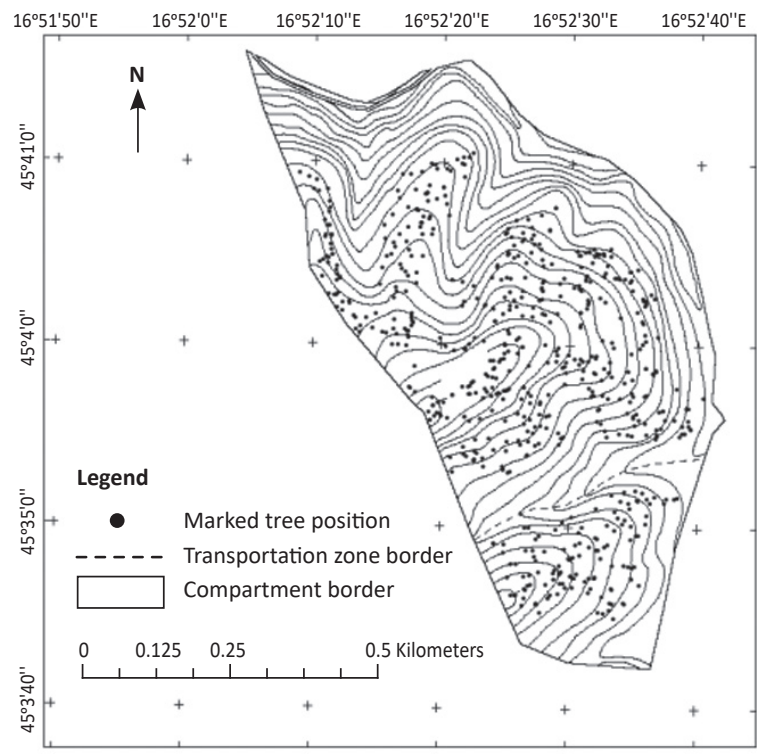

FIGURE 2. Position of marked trees in the investigated compartment 
The unit cost of the construction of skid roads is determined on the basis of bulldozer productivity of 0.0475 $\mathrm{h} \cdot \mathrm{m}^{-3}$ and its labor cost of $35.90 € \cdot \mathrm{m}^{-3}$, thus amounting to $1.71 € \cdot \mathrm{m}^{-3}$ of soil [9]. Total cost of the construction of skid roads is the product of unit cost of the construction and the volume of earthwork. The volume of earthwork is determined on the basis of terrain slope at the station points of the skid road, which are laid at each $50 \mathrm{~m}$ of the road, and length of the skid road (Figure 3).

\section{Calculation of Average Skidding Distance and the Costs of Wood Skidding}

Winching distance is obtained by spatial analysis tools. Path distance tool is used to make a 3D raster of distance in the whole compartment, from each part of the secondary forest road network, and each marked tree is assigned a distance by the extract tool. On the basis of the distance of marked trees their affiliation is determined by a certain part of secondary forest road network, while the winching distance is calculated by Equation 1:

$$
S d_{w}=\frac{\sum L_{i w} \cdot V_{i}}{\sum V_{i}}(m)
$$

where: $S d_{w}$ - average winching distance, $L_{i w}$ - length of each winching, $V_{i}$ - volume of winched roundwood.

Average skidding distance is defined as weighted average distance of all marked trees from skid roads or trails. For this task, Locate Feature Along Routes tool is used. Secondary forest road network is divided into gravitation zones. Gravitation zones include the parts of network leading to one landing, and skidding distance of the marked trees is determined between them and the landing (Equation 2):

$$
S d=\frac{\sum L i \cdot V_{i}}{\sum V_{i}}(m)
$$

where: Sd - average skidding distance, $L_{i}$ - length of skid $\mathrm{road} /$ trail, $\mathrm{V}_{\mathrm{i}}$ - volume of skidded roundwood.

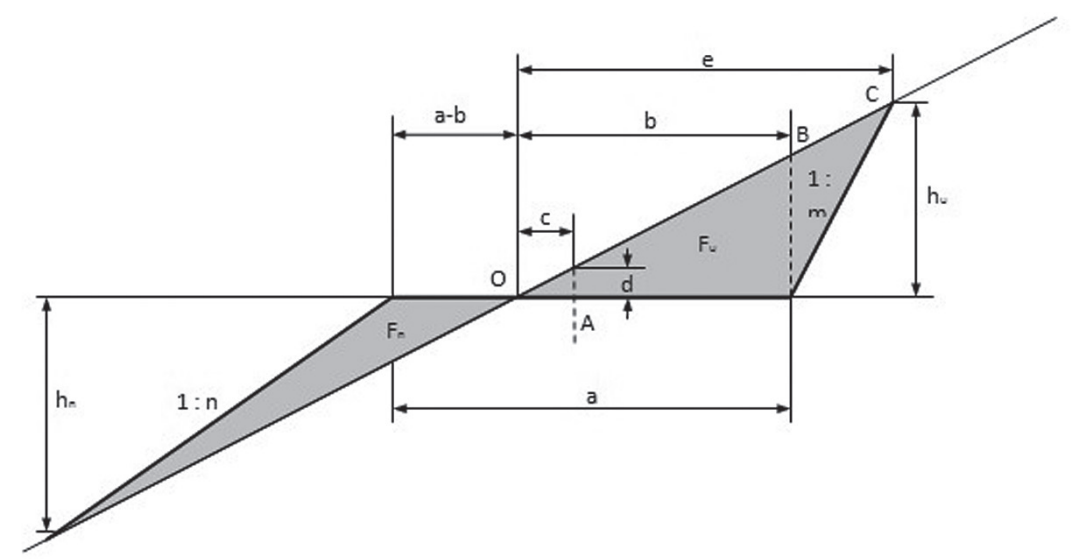

FIGURE 3. Cross section of the skid road.

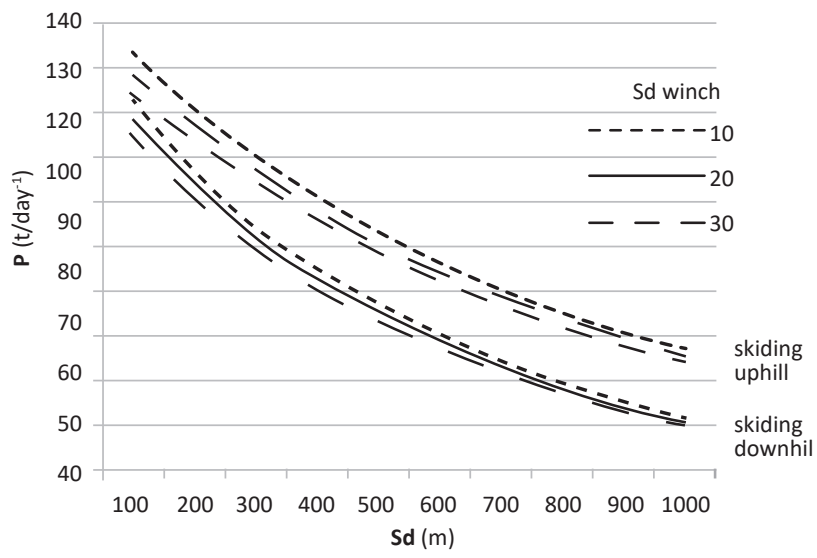

FIGURE 4. Diagram of productivity for different winching and skidding distances. 
Determining of average skidding distances in this way is adapted to the application of the technical norms for wood skidding which are part of the Tables of Technical Standards in forest exploitation [32] (Figure 4).

According to these tables, the skidding costs are determined by the average skidding distance to the individual landings or for the entire compartment, whereby differences in productivity are the result of mean skidding distance, mean winching distance and skidding direction. In order to calculate work productivity, the tables for medium heavy articulated skidders were used in the dry to wet conditions of the soil and for skidding downhill or uphill. The average diameter of the marked tree is $51 \mathrm{~cm}$ and consequently the entry into the table used is the average piece volume of $1.00 \mathrm{~m}^{3}$. As the performance rate was given in $t \cdot$ day $^{-1}$, the transformation in $\mathrm{m}^{3}$. day ${ }^{-1}$ was performed using the ratio of 1:1.25 for fresh softwood and 1:1 for fresh beech.

\section{Designing of Secondary Forest Road Network Variants}

In this investigation the new secondary road network is laid in the field and it is compared with three simulated variants of secondary network that are laid by ArcGIS 10.3. These variants are based on different average winching distances of 10,20 and $30 \mathrm{~m}$.

Secondary forest road network is planned by using Network Analyst tools and Shortest Path method of the ArcGIS 10.3 software. The last method is based on Dijkstra's algorithm. Dijkstra's algorithm provides the shortest paths from a node to each of the other nodes of the graph [33]. In general, the shortest path is the problem of finding a series of road links connecting two nodes in a way that the sum of the weights on those edges is minimized [34].

The Network Analyst method intends to set up a network of points at a distance of $20 \mathrm{~m}$ in the digital map of the research area. These points are linked by lines that are potential parts of secondary forest road network. Every point is connected with neighboring points by 32 lines in the combination: $1+1$, $1+2,2+1,1+3,3+1,2+3$ and $3+2$ (Figure 5). The aim of this method is to cover as large a research area as possible by potential routes of the secondary forest road network. This spatial layout of points achieved minimal length of $20 \mathrm{~m}$ and maximal length of $72.11 \mathrm{~m}$ of potential routes. The grade of every link between points is determined based on distance and height difference between them (Equation 3):

$$
i=\frac{\Delta h}{d} \cdot 100(\%)
$$

Height distance is the difference between altitudes of points, and their altitudes are obtained from DEM.

Djikstra's algorithm is used for the links whose slope is up to $30 \%$, and this slope is maximal allowed for route of secondary forest traffic network. Regarding terrain slope, terrain with a slope of over $65 \%$ should be avoided during the marking of trees and setting up of skid roads or skid trails in the field. For laying different routes of secondary forest road network three points are used. The primary aim of laying secondary forest road network is to make all marked trees available for skidding and winching for the average or maximal length of rope. This is achieved by creating of 3D border zone around routes of the secondary forest road network. The additional routes of its transport network are laid in the case when a marked tree is out of the border zone.

\section{RESULTS AND DISSCUSION}

\section{Marking Trees for Cutting and Real Skid Network}

In the investigated compartment 642 trees of beech, fir and other hardwoods are marked for cutting. Total cutting volume is $2,397.01 \mathrm{~m}^{3}$ with roundwood volume of $1,233.51$ $\mathrm{m}^{3}$. Cutting density in the whole compartment is 51.31 $\mathrm{m}^{3} \cdot \mathrm{ha}^{-1}$. However, due to extremely steep slopes in some compartment areas, trees are marked only on 20.77 ha, or $44 \%$ of the total compartment area. This makes real cutting density of $115.41 \mathrm{~m}^{3} \cdot \mathrm{ha}^{-1}$ or $59.39 \mathrm{~m}^{3}$ of roundwood per unit area. The whole area of the compartment is spatially divided into two transportation zones from which roundwood is skidded in different directions on two landings, located on the forest roads. Downhill $956.24 \mathrm{~m}^{3}$ are skidded, and uphill $277.27 \mathrm{~m}^{3}$ from an area of 16.82 ha and 3.95 ha respectively.

Total length of the secondary road network (Figure 6a) designed in the compartment is $4,816 \mathrm{~m}$, thus achieving the secondary openness of $103 \mathrm{~m} \cdot \mathrm{ha}^{-1}$. For their construction, according to an operational study, including the construction of new landings and clearing the existing ones, $392.64 €$ is needed. Small costs like this are the result of an already developed network of secondary roads from previous cutting cycles in the compartment. During the last cutting, only 170
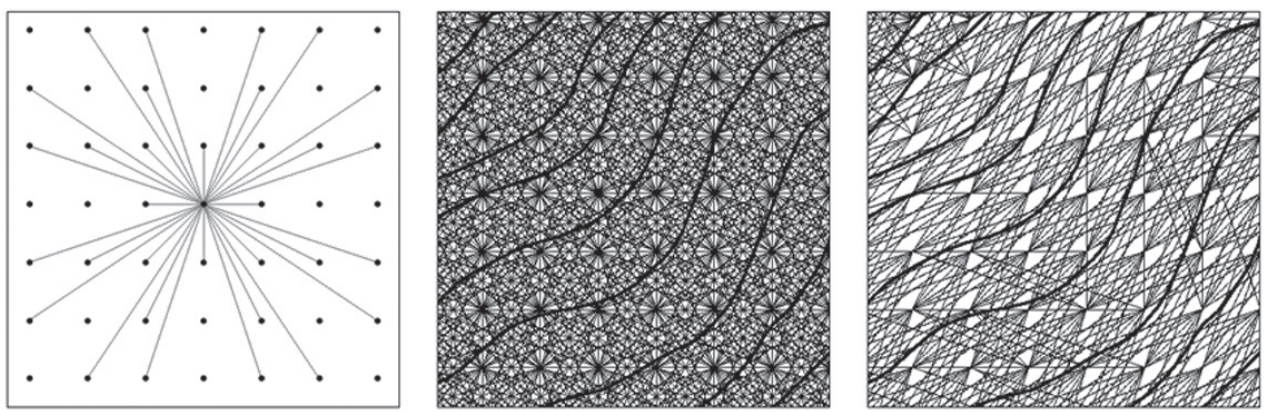

FIGURE 5. Connection pattern (left), whole network (mid), network of segments less than $30 \%$ (right). 
$m$ of new skid roads is added to the existing network. With the assumption that in the compartment an already built secondary road network does not exist, the length of skid roads for which it is necessary to calculate construction costs is $1,712 \mathrm{~m}$, while $1,397.66 €$ is needed for the construction.

\section{Designing Variants of the Skid Network}

In the compartment, 1,173 points are interconnected with 20,777 segments of all slopes. Maximum slope for skid roads is defined by $30 \%$, and the total number of segments used for the Dijkstra algorithm is 12,151 .

\section{Variant I}

This variant (Figure 6b) of the secondary forest road network in the compartment is adjusted to the maximum winch pulling distances of $20 \mathrm{~m}$, and as a result of that in this variant the total length of the secondary road network is projected to be $8,441 \mathrm{~m}$, thus achieving an openness of 181 $\mathrm{m} \cdot \mathrm{ha}^{-1}$. This network variant consists of 62 secondary roads. Fulfilling the conditions of the maximum length of the rope and the design of the secondary road on terrain slopes under $65 \%$, and in order to ensure skidding of the total amount of wood, another landing was introduced in the transport zone from which wood is skidded downhill. In the category of skid roads, the total projected length is $5,590 \mathrm{~m}$ and the construction costs for this network are 14,352.62 €.

\section{Variant II}

The maximum planned winch rope length in this variant is $40 \mathrm{~m}$, while the planned network consisted of 32 skid routes with 6,184 m in length, which gives an openness of $132 \mathrm{~m} \cdot \mathrm{ha}^{-1}$ (Figure $6 \mathrm{c}$ ). In this variant of the network, the total amount of wood is skidded to the three landings. Total length of planned skid roads is $3,288 \mathrm{~m}$ and construction costs are 7,426.68 $€$.

\section{Variant III}

This variant of the secondary network is most similar to the actual network since the maximum allowable winch rope length is $60 \mathrm{~m}$ (Figure $6 \mathrm{~d}$ ). This variant guarantees the maximum distance between individual secondary roads and their minimum length at the same time. The planned network consists of only 18 secondary forest roads and has a length of $4,842 \mathrm{~m}$ and openness of $104 \mathrm{~m} \cdot \mathrm{ha}^{-1}$. The construction cost of this variant amounts to $4,440.89 €$ for $2,219 \mathrm{~m}$ of skid roads.

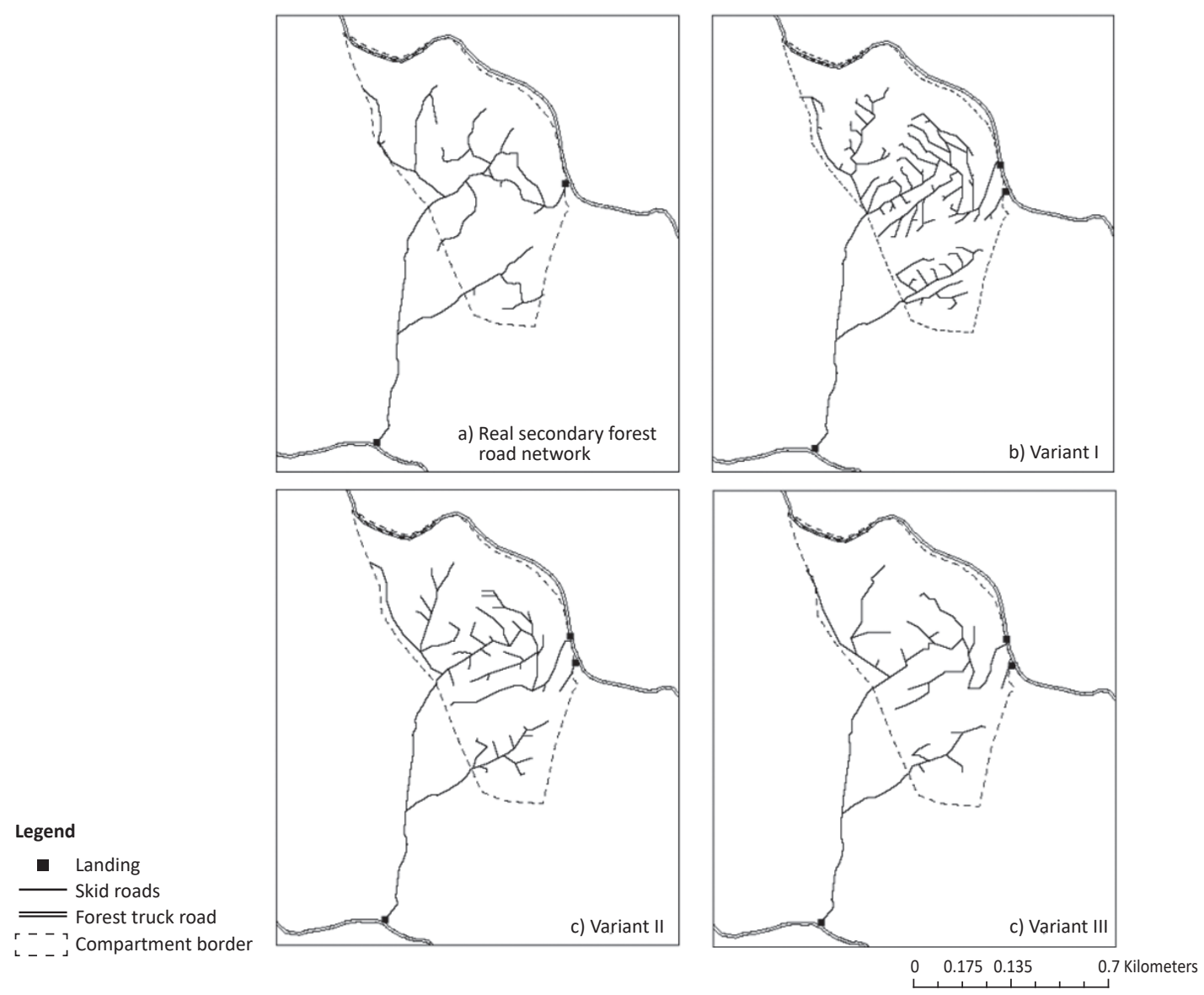

FIGURE 6. Secondary forest network designed in the field (a) and simulated in the office by ArcGIS (b, c, d). 
TABLE 1. Mean skidding distance, productivity and skidding costs for the existing network and designed variants.

\begin{tabular}{cccccc}
\hline & & Actual network & Variant I & Variant II & Variant III \\
\hline \multirow{2}{*}{ Average skidding distance $(\mathrm{m})$} & Downhill & 690 & 760 & 740 & 710 \\
\cline { 2 - 6 } & Uphill & 990 & 920 & 910 & 920 \\
\hline \multirow{2}{*}{ Productivity $\left(\mathrm{m}^{3} \cdot\right.$ day $\left.^{-1}\right)$} & Downhill & 83.89 & 83.57 & 82.92 & 82.90 \\
\cline { 2 - 6 } & Uphill & 55.71 & 59.99 & 59.50 & 58.26 \\
\hline \multirow{2}{*}{ Skidding costs $\left(€ \cdot \mathrm{m}^{-3}\right)$} & Downhill & 6.85 & 6.88 & 6.93 & 6.94 \\
\cline { 2 - 6 } & Uphill & 10.32 & 9.58 & 9.66 & 9.87 \\
\hline
\end{tabular}

Compared to the mean skidding distance for skidding with the wheeled skidder according to Pičman et al. [35], which amounts to $300 \mathrm{~m}$ uphill and $800 \mathrm{~m}$ (1000 $\mathrm{m})$ downhill respectively, in this investigation in case of downhill skidding for all variants the mean skidding distances are twice longer. In general, extraction process in the compartment is relativelly unfavorable. Apart from long skidding in the downhill direction, when skidding uphill the mean skidding distance is almost $1000 \mathrm{~m}$ long, which produces high skidding costs. Petković et al. [36] stated that in such cases when different directions of skidding exist, minimum costs can be achieved by optimum skidding pattern.

When talking about absolute openess, achieved values in all variants including the existing network of secondary forest roads are in the interval defined by Jeličić [5]. According to Danilović and Ljubojević [37], average density of the secondary forest road network for nine analysed compartments in Management Unit "Prosara" amounts to $105 \mathrm{~m} \cdot \mathrm{ha}^{-1}$. Almost the same values are achieved in the third variant of the designed and the actual network of secondary roads. On the other hand, within defined sample Petković et al. [36] found that the density of secondary roads in MU "Prosara" is $119.7 \mathrm{~m} \cdot \mathrm{ha}^{-1}$ and in MU "KozaraMlječanica" $96.5 \mathrm{~m} \cdot \mathrm{ha}^{-1}$. Differences between individual compartments are expected because density of skid roads and skid trails is not only a function of winch rope length.

In comparison with the actual position of secondary network in the compartment, where the length of the skid roads is only $35 \%$ of the total network length, in all simulated variants the skid road share is more than $60 \%$, and in Variant I even $77 \%$. The rest are skid trails. This is the main reason why the cost of building the actual network of skidding communications in the compartment is almost 3 times smaller than the cost of network construction in Variant III, although these two variants have almost identical overall length of the network. When designing field secondary roads, they mostly represent skid trails, such as the ones on the ridges or positioned perpendicularly on the contours. The slope of these trails often exceeds the $30 \%$ limit defined here, especially when it comes to skidding downhill.

The achieved mean skidding distances are relatively similar in all variants. This is somewhat expected since the road network in all variants leads to two or three landings. However, when taking into account average length of the winch rope, considering all three new-design variants, it can be said that there is almost no difference in productivity and skidding costs (Table 1). As network construction costs exponentially grow from Variant III to Variant I, without reducing the skidding costs, from an economical point of view the construction of this network is unacceptable. Imani et al. [38] compared the forest roads variants obtained by Dijkstra's method and the traditional method and found that by using the first method they obtained lower length and costs for 55\% and 65\%. Parsakhoo et al. [39] obtained shorter routes by $12.03 \%$ in average, by using Dijkstra's algorithm. In this investigation, by using the method of the shortest route, longer routes were obtained in relation to the existing network that is laid in a traditional way.

Sokolović et al. [40] state that the minimum transport costs could be achieved by using winch rope length of 40$60 \mathrm{~m}$. It is not recommended to use longer rope in sense of labour humanization during skidding and residual stand damage. In Management Unit "Bovan-Jelar", Pičman et al. [41] during the improvement of the existing secondary forest road network and adjustment to demanding terrain conditions used winch rope length of $45 \mathrm{~m}$.

Surface of the investigated compartment covered by secondary roads is between $3.6 \%$ and $6.3 \%$, at road width of $3.5 \mathrm{~m}$. Another topic for discussion could be load of each road network. In Figure 7 it is presented how each network variant is loaded depending on distance. It can be seen that secondary road network variants with shorter winching distances are less loaded than those with longer distances, and real network is closest to Variant III. This fact could have impact on durability and maintenance of the secondary road network.

\section{CONCLUSIONS}

Mean winching distance influences skidding costs, but only in variants where mean skidding distance is decreasing. For all three designed networks of secondary forest roads in the compartment, it has almost no effect on the reduction of mean skidding distance. Therefore, a dense network of secondary forest roads is justified only in those cases where smaller distance of winching is needed for some other reason, e.g. for a higher level of work humanization or ecological reasons. On the other hand, smaller winching distance requires more skid roads and skid trails, which is unfavorable from both the economic 


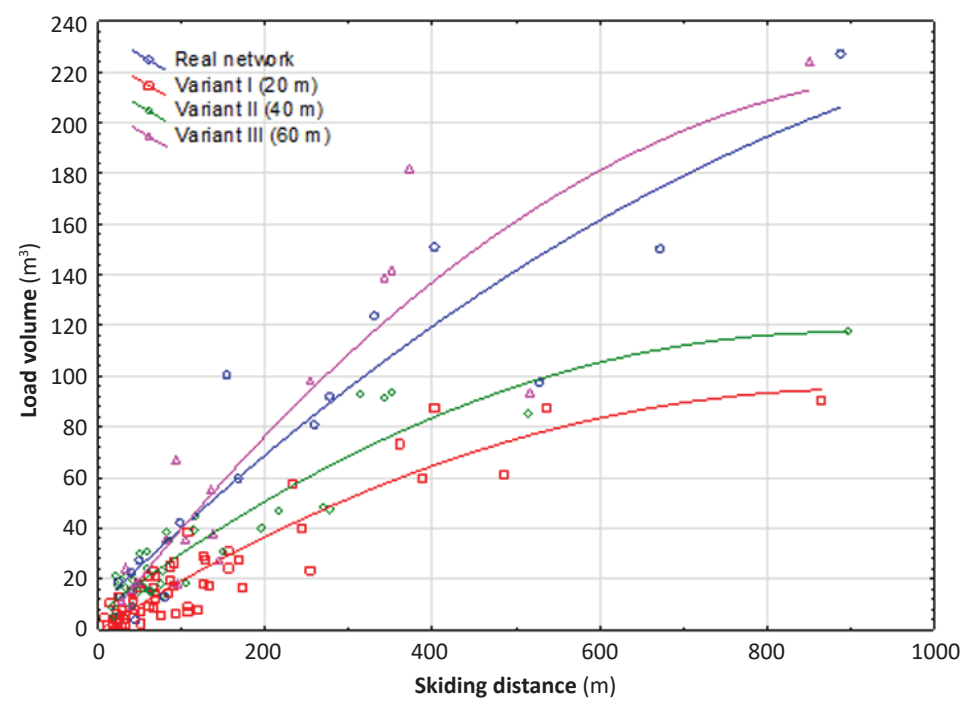

FIGURE 7. Load of skid network in different variants.

and ecological point of view, especially on steep slopes. In the end with the degree of density of secondary forest roads will be decided on the basis of archived average price of wood assortment and environmental guidelines. Small differences in skidding costs between variants have no practical significance except for large quantities of wood assortments. Spatial and network analysis tool is useful for secondary forest road network development and especially for large forest areas where there is a significant potential for this method. Another aspect is related to the primary and secondary openness of forest areas. Such tools, including network algorithms such as Dijkstra's algorithm, need greater attention in road network planning processes.

\section{REFERENCES}

1. IUFRO 1995 Forest work study. Nomenclature. Test Edition valid 1995-2000. International Union of Forestry Research Organisations WP 3.04.02, Swedish University of Agricultural Sciences, Department of Operational Efficiency, Garpenberg, Sweden, $16 \mathrm{p}$

2. DOBRE A 1995 Forest roads. Biotechnical faculty, Department for forestry and renewable forestry resources, Ljubljana, Slovenia, $70 \mathrm{p}$

3. POTOČNIK I 2004 Forest network. Manuscript, University of Banja Luka, Faculty of Forestry, Banja Luka, Bosnia and Hezegovina, $73 p$

4. SOKOLOVIĆ DŽ, BAJRIĆ M 2013 Forest opening. University of Sarajevo, Faculty of Forestry, Sarajevo, Bosnia and Hezegovina, $250 p$

5. JELIČIĆ V 1983 Forest roads and trails. SIC Education and training SRH. Zagreb, Croatia, $192 \mathrm{p}$

6. JELIČIĆ V 1977 Opening of cutting area with forest road network in forests of beech, fir and spruce. Worksof the Faculty of Forestry University of Sarajevo21 (1-2): 65-97

7. BOJANIN S 1983 Factors of optimal openness in secondary openings. Mehanizacija šumarstva 11-12 (8): 322-325

8. FAO 1998 A Manual for the Planning, Design and Construction of Forest Roads in Steep Terrain. Food and Agriculture Organization of the United Nations (FAO), Rome, Italy, 130,15 p
9. PUBLIC FORESTRY COMPANY "ŠUME REPUBLIKE SRPSKE" 2017 Rulebook about designing, construction, maintenance and reconstruction of tractor roads and trails. Banja Luka, Bosnia and Herzegovina, $18 p$

10. DYKSTRA D P, HEINRICH R 1996 FAO model code of forest harvesting practice. Food and Agriculture Organization of the United Nations (FAO), Rome, Italy, $75 \mathrm{p}$

11. MARČETA D, PETKOVIĆ V, KOŠIR B 2014 Comparison of two skidding methods in beech forests in mountainous conditions. Nova mehanizacija šumarstva 35(1): 51-62

12. REBULA E 1983 Optimal density of skid trails. Mehanizacija šumarstva 8 (3-4): 317-321

13. URADNI LIST REPUBLIKE SLOVENIJE 2004 Rules on forest roads. Uradni list Republike Slovenije RS 104/2004 URL: $\quad$ https://www.uradni-list.si/glasilo-uradni-list-rs/ vsebina?urlid=2004104\&stevilka $=4445$

14. PIČMAN D 2007 Forest roads. University of Zagreb, Faculty of Forestry, Zagreb, Croatia, $460 \mathrm{p}$

15. ZDJELAR M 1990 The impact of skid road construction methods on work productivity and efficiency, tree damage and work load. Mehanizacija šumarstva 15 (1-2): 3-26

16. [31] PETKOVIĆ V, POTOČNIK I 2018 Planning forest road network in natural forest areas: a case study in Northern Bosnia nad Hrzegovina. Croat J For Eng 39 (1): 45-56 
17. PARSAKHOO A, LOTFALIAN M 2017 Locating log depots and forest roads using a weighted-graph optimization algorithm. Nova mehanizacija šumarstva 28: 67-77

18. CHUNG W, SESSION J 2001 Designing of forest road network using Heuristic optimization techniques. In: Conference Proceedings: Appalachian Hardwoods: Managing Change. Council on Forest Engineering , Snowshoe, USA, 15-18 July 2001

19. HEINIMANN HR 2017 Forest Road Network and Transportation Engineering-State and Perspectives. Croat J For Eng 38 (2): 155-173

20. SESSIONS J, CHUNG W 2003 NETWORK 2000: A program for optimizing large fixed and variable cost transportation problems. In: Arthaud GJ, Barett TM (eds) Systems Analysis Symposium in Forest Resources: Systems Analysis in Forest Resources: Proceedings of the Eighth Symposium, Snowmass Village, Aspen, Colorado, USA, 28-30 September. Volume 7, Managing Forest Ecosystems. Kluwer Academic Press, Dordrecht, the Netherlamds, pp 81-86

21. ANDERSON AE, NELSON J 2004 Projecting vector-based road networks with a shortest path algorithm. Can J Forest Res 34 (7): 1444-1457. DOI: https://doi.org/10.1139/x04030

22. STÜCKELBERGER J, HEINIMMAN HR, CHUNG W 2007 Improved road network design models with the consideration of various link patterns and road design elements. Can J Forest Res 37 (11): 2281-2298. DOI: https://doi.org/10.1139/X07-036

23. CHUNG W, STÜCKLEBERGER J, ARUGA K, CUNDY WT 2008 Forest road network design using a trade-off analysis between skidding and road construction costs. Can J Forest Res 38 (3): 439-448. DOI: https://doi.org/10.1139/X07-170

24. NAJAFI A, RICHARDS WE 2013 Designing a Forest Road Network Using Mixed Integer Programming. Croat J For Eng 34 (1): 17-30

25. JOURGHOLAMI M, ABDI E, CHUNG W 2013 Decision making in forest road planning considering both skidding and road costs: a case study in the Hyrcanian Forest in Iran. iForest 6: 59-64. DOI: https://doi.org/10.3832/ifor0640-006

26. PARSAKHOO A 2016 Technical assessment of forest road network using Backmund and surface distribution algorithm in a hardwood forest of Hyrcanian zone. Forest Syst 25: e059. DOI: https://doi.org/10.5424/fs/2016252$\underline{07815}$

27. SABO A 2000 Timber skidding by skidder LKT 81 from selection stands with different degrees of forest opening in Gorski Kotar. MSc thesis, University of Zagreb, Faculty of Forestry, Zagreb, Croatia, $142 \mathrm{p}$

28. BEMBENEK M, MEDERSKI PS, ERLER J, GIEFING DF 2011 Results of large-size timber extracting with a grapple skidder. Acta Sci Pol Silv 10 (3): 5-14
29. SABO A, PORŠINSKY T 2005 Skidding of fir roundwood by Timberjack 240C from selective forests of Gorski Kotar. Croat J For Eng 26 (1): 13-27

30. PORTER B, STRAWA P 2006 Analysis of logging and skidding operations in fir stands. Sylwan 1: 67-72

31. DRINIC P, MATIC V, PAVLIC J, PROLIC N, STOJANOVIC O,VUKMIROVIC V 1980 Table of inventory elements for high forests in Bosnia and Herzegovina. University of Sarajevo, Faculty of Foresty, Sarajevo, Bosnia and Herzegovina, $246 \mathrm{p}$

32. ŠIPAD IRC OOUR SILVA 1989 Tables of technical standards in the forests exploitation. Sarajevo, Bosnia and Herzegovina, $175 \mathrm{p}$

33. PICARD N, GAZULL L, FREYCON, V 2006 Finding Optimal Routes for Harvesting Tree Access. Int J Forest Eng 17 (2): 35-48

34. AKAY AE, ARUGA K, BETTINGER P, SESSIONS J 2013 Using Optimization Techniques in Designing Forest Roads and Road Networks. Bartin Orman Fakültesi Dergisi 15 (1): 49-62

35. PIČMAN D, PENTEK T, PORŠINSKY T 2001 Relation between Forest Roads and Extraction Machines in Sustainable Forest Management. In: Arzberger $\mathrm{U}$, Grimoldi M (eds) FAO/ECE/ILO \& IUFRO Workshop on "New Trends in Wood Harvesting with Cable Systems for Sustainable Forest Management in the Mountains" Ossiach, Austria, pp 1-8

36. PETKOVIĆ V, MARČETA D, LUUBOJEVIĆ D, POTOČNIK I 2017 Optimization of calculation of skidding correction factor in Forest Administration "Prijedor" Prijedor. Bulletin of Faculty of Forestry University of Banja Luka 27: 41-50

37. DANILOVIĆ M, LJUBOJEVIĆ D 2013 Forest opening with secondary forest road network. Bulletin of Faculty of Forestry University of Belgrade 108: 25-38

38. IMANI P, NAJAFI A, GHAJAR I 2012 Planning forest road alignment using a shortest path algorithm. In: Pentek T, Poršinsky T, Šporčić M (eds) Forest Engineering - Concern, Knowledge and Accountability in Today's Environment, Proceedings of 45th International Symposium on Forestry Mechanization, Dubrovnik, Croatia, 8-12 October 2012. Forestry Faculty of University Zagreb, Zagreb, Croatia, pp 1-5.

39. PARSAKHO A, MOSTAFA M, SHATAEE S, LOTFALIAN M 2017 Decsion support system to find skid trail network for extracting marked trees, J For Sci 63 (2): 62-69. DOI: https://doi.org/10.17221/36/2016-JFS

40. SOKOLOVIĆ D, KOLJIĆ H, HALILOVIĆ V, GURDA S, BAJRIĆ M, MUSIĆ J 2011 Winch rope length as factor in optimisation of tractor road network. Naše Šume 9 (22/23): 11-23

41. PIČMAN D, PENTEK T, NEVEČEREL H, PAPA I, LEPOGLAVEC K 2011 Possibilities of application of relative openness in secondary forest opening of slope forests in Croatia. Croat J For Eng 32 (1): 417-427 